\title{
How Do Literary Works Cross Borders (or Not)?
} A Sociological Approach to World Literature

\author{
Gisèle Sapiro \\ CNRS and École des hautes études en sciences sociales \\ sapiro@ehess.fr
}

\begin{abstract}
This paper analyzes the factors that trigger or hinder the circulation of literary works beyond their geographic and cultural borders, i.e. participating in the mechanisms of the production of World Literature. For the sake of analysis, these factors can be classified into four categories: political (or more broadly ideological), economic, cultural and social. Being embodied by institutions and by individual agents, these factors can support or contradict one another, thus causing tensions and struggles. This paper ends with reflections on the two opposite tendencies that characterize the transnational literary field: isomorphism and the differentiation logics.
\end{abstract}

\section{Keywords}

World Literature - sociology of literature - sociology of translation - international circulation of literature - field theory

If we consider world literature as referring to those literary works that circulate beyond their national borders (Damrosch), then we have to ask how these works circulate, and what obstacles they encounter (Apter). These obstacles are not only linguistic; there are many social obstacles, just as there are social factors that trigger the circulation of texts regardless of their intrinsic value. A sociological approach is thus required in order to identify these factors and the mechanisms of production of World Literature as well as its specific hierarchies (Casanova).

In a seminal paper on "[t]he social conditions of the circulation of ideas," Pierre Bourdieu outlined a program for studying the strategies elaborated by individuals or groups implied in this process (Bourdieu "Social Conditions"). 
This approach stems from the postulate that ideas do not spread mechanically by spiritual contagion (Tarde), but that they are mediated by material means, such as books, newspapers, journals, and the internet, or by oral diffusion in public or private settings. Consequently, the sociology of transnational cultural exchanges has focused on the agents-individuals, groups, institutions-that participate in this circulation: authors, publishers, state representatives, literary agents, translators, and critics, in the case of literary works (Heilbron and Sapiro). Relying on different sources (UNESCo's Index Translationum, national bibliographies, professional bookstores database, publishers' catalogues, lists established by state representatives), the construction of databases of works in translation in various languages has supplied data for statistics of flows. Applying the world system frame of analysis to the flows of book translation across languages (Heilbron), countries (Popa), and cities (Sapiro "Globalization") has documented the asymmetries of exchanges between centers and peripheries. These databases are also a rich source for the study of what is translated from one language to another, and by whom (Popa; Sapiro Translatio; Sapiro "Symbolic Capital"). Such quantitative data displays patterns and regularities that help us understand the factors that may hinder or trigger the circulation of symbolic goods in a particular context, and raises the question of mediators' motivations. The hypotheses may be confirmed or revised in the light of qualitative data such as (auto)biographies and memoirs, archives, interviews, critical reception in the media, and cultural events, such as book fairs, festivals and literary prizes.

These factors can be divided for the sake of analysis into four categories: political, economic, cultural, and social factors. Literary scholars and specialists of translation studies usually focus on the cultural factors and on texts. Historians working on cultural transfers have taken into account the political factors as well and the role of actors, but have neglected the economic aspects, while historians of publishing have paid little attention to the issue of translation until recently. The social factors were mainly identified in postcolonial and gender studies and by sociologists of culture. In most cases, these four types of factor are embedded together, but in some contexts, one type may prevail and subordinate the others. I will present them here separately, providing examples of each, in order to propose a framework of analysis of the social condition of circulation of literary works. In the conclusion, I will discuss some theoretical issues about socio-historical dynamics: while cultural transfers can be partly described in terms of isomorphism - whether due to imitation, constraints, or shared norms, as analyzed by neo-institutional theory (DiMaggio and Powell)—accounting for these transfers also requires us to introduce the logics of differentiation. Combining 
these two processes provides an explanatory frame for the two evolutionary models mentioned by Franco Moretti: waves and trees.

\section{Political Factors}

Political and broader ideological factors may trigger or hinder the circulation of literary texts. Translation may serve political or ideological objectives; it can be a means to disseminate a doctrine or a vision of the world. Parties and political organizations have contributed to the international circulation of works like that of Marx and Engels, through more or less organized networks, and to the building of a world canon of socialist realism. Lenin was the most translated author between 1955 and 1980, according to the Index Translationum database (Venuti 158).

However, this dissemination strategy can be countered by legal means. States have imposed legal frontiers through copyright, legal restrictions on the press, and political control on the circulation of print, which varies according to the degree of authoritarianism vs. liberalism. Foreign publications often have a specific status and are submitted to more severe control than publications in the national language. For instance, whereas in 1956 the original publication of Nabokov's Lolita in English in Paris by Olympia Press was forbidden by the Ministry of the Interior, Gallimard had no trouble in releasing the French translation three years later. This cannot be explained only by the sulphurous reputation of Olympia Press compared to the prestige of Gallimard. In the context of reinforced state control over publishing during the Algerian war, neither was it the result of liberal evolution, but the expression of the accrued suspicion of foreign publications. This example shows that translation may be a way to circumvent censorship. However, the very first attempt to publish the original book in France also attests to the constraints the author had to face in his own country, the United States, which was less liberal than France. William Burroughs was confronted with similar constraints with Naked Lunch: first published in English in Paris by Olympia Press in 1959, then translated into French by Gallimard, which this time had some difficulties with censorship, it was republished, in a different version, by Grove Press in 1962 and was banned for obscenity in Boston and Los Angeles, until the Massachusetts Supreme Court reversed the decision in 1966.

Less risky than underground publication (called samiszdat in Russian), while ensuring a broader audience, publishing abroad was a strategy adopted by many oppositional writers in authoritarian countries, whether in the original language or in translation, as in the case of Pasternak's Doctor Zhivago, first 
published in Italy in 1957 by Feltrinelli, or of Milan Kundera's novels, published in French translation before he emigrated to Paris (Popa). In countries where the economic field is subordinated to the political field, and where the institutions governing cultural production as well as the organization of intellectual professions are state-run, as in fascist or communist countries, the production and circulation of symbolic goods are highly politicized (Sapiro "Literary Field"; on translation of children's books in the German Democratic Republic, see Thomson-Wohlgemuth; on translations in Fascist Italy, see Rundle). During the German occupation in France, the Third Reich forbad translations from French into German, except for a few writers who were active supporters of collaboration. At the same time the German occupying forces required French publishers to translate as many German authors as possible, as part of their policy to break France's cultural hegemony: Gallimard published for instance a couple of titles by Ernst Jünger (Loiseaux 110-111).

Translation is indeed an issue at stake in power relations between countries, beyond any political consideration. For a nation-state, exporting its literature in translation is a sign of its symbolic recognition on the international scene. This is why many states allocate financial support to this exportation. However, state policies in support of translation may at times be embedded in a broader political strategy: for example, in Israel, one of the official justifications for the public subvention accorded to the Institute for the Translation of Hebrew Literature was that it would help improve the image of the country, which was internationally censured for the occupation of the Palestinian territories (interview with the Head of the Institute, October 31, 2001). On the other hand, state support for the translation of foreign works into the domestic language can be justified by educational or scientific goals of reaching a certain level, or of "catching up" to international standards, as the case of Arab countries illustrate (Jacquemond). In these cases, political and cultural factors are intertwined. Economic factors such as supporting the national publishing industry may also be used as a justification for state intervention in favor of translation, as is the case in France today. However, state agents who launched policies in favor of translations from and into French in the late 1980 os had more culturally oriented motivations, and intended to counterbalance the effects of market logics on the international circulation of books, especially the reduction of cultural diversity and the growing domination of English. 


\section{Economic Factors: The Logics of the Market}

The circulation of works in print depends on the book and press industries and on distribution networks. The capitalist development of publishing gave a strong impulse to this circulation, which was fostered at the turn of the nineteenth century by industrialization and later on by the development of new means of transportation. Book production was concentrated in cities such as Leipzig, Paris, and London, which therefore became cultural centers of linguistic areas. However, the circulation of books in such areas depends on distribution as well as production networks. Despite a long publishing tradition concentrated in Beirut and Cairo, the lack of such networks still limits the circulation of books across the Arab-speaking countries today. Competition between countries may also impede it, as the Latin American case illustrates: attempts of the French government to facilitate co-publication of translations from French into Spanish with publishers from different Latin American countries encounter much reluctance (interview with a French representative in Santiago de Chile, March 2008).

The print market is thus structured around two types of frontiers: cultural (linguistic) and political. Crossing legal borders within the same linguistic area depends on political, economic and cultural power relations between countries. For instance, Hachette International, now a subsidiary of the conglomerate Lagardère, holds $85 \%$ of the shares in the educational book market in former French colonies in Africa, where the book industry is underdeveloped (Perucca; Pinhas).

The international book market has been regulated since 1886 by the Berne Convention for the Protection of Literary and Artistic Works, which requires publishers to buy distribution or translation rights for books from their original publisher or literary agent during the period to which the copyright law applies (often 70 years, though the duration varies across countries). The law on copyright, contributed to the professionalization of publishing and to the establishment of norms in the book market, all the while protecting the author and the translator from plagiarism, yet it can also be regarded as a limitation on the circulation of books which reinforces the power of the publishing centers, since many publishers in poor countries do not have the means to buy the rights (Venuti 161). By subscribing to the moral rights as defined in French law on authors' rights (droit d'auteur), the Berne Convention also guarantees the author a droit de regard over the translated work (choice of publisher and translator, quality of the translation, changes in the text). The United States never subscribed to the Berne Convention because of this clause on moral rights, which it considered as an obstacle to free trade. For this reason, the 1994 WTO 
agreement on trade-related aspects of intellectual property rights (TRIPS) circumvents the clause of moral rights. As a consequence, this agreement could destabilize the norm of respecting the original text that has prevailed in upmarket publishing since the Berne Convention, but such an evolution is curtailed through the use of contracts in which the original publisher can request that no cuts or changes be introduced in the work as well as negotiate a droit de regard for the author.

The delimitation of "territories" for books circulating in and across linguistic areas is also an issue at stake in the negotiation of contracts. Publishers tend to demand worldwide translation rights, while the original publisher may try to split the rights between two different publishers in the same language, who will then append the territories of distribution to their contracts (with the uncovered areas then defined as "open market"). British publishers usually consider European countries and former colonies like India as their territories, while American publishers try to extend theirs beyond North America to the Pacific, as this extract from an interview with the head of an upmarket imprint belonging to a large multinational conglomerate shows:

We always have a list of territories appended to our contracts, and this has to do with the open market so that we are very careful to try and get as many territories as we can. And the British publishers traditionally had all the territories that used to be in the old British Commonwealth when Britain was [an] empire, and the United States has had [to] chip away very hard at that because there is no empire and why should you automatically get the right to sell in India, India is not your colony anymore and neither is South Africa, neither is Singapore or Malaysia or Hong Kong. We face the Pacific from California actually, it is easier for us to market there ... Yes, you can have Europe because it is right across the channel. But why shouldn't we have Asia? We'll battle you for South America and Africa and Asia as well. So it is constantly a matter of contention. The thing that makes me laugh is that I bought a book from a British publisher, and I looked at their schedule of territories, arranged by continent. And they actually had Antarctica. Underneath, "British Antarctica." Antarctica is divided, so they had British Antarctica in their territories, which made me laugh out loud, I'd never seen anything like that ... but they have it on their schedule of territories just so that we, Americans, don't think we can peddle a book into Antarctica. That was really funny.

interview, October 5, 2007 
Economic considerations are thus involved in the production and circulation of books and in many cases prevail over other considerations. This is especially true in countries where the book market is liberalized. In the United States and the United Kingdom, cultural goods appear primarily as commercial products that must obey the law of profitability. This is best illustrated by the process of manufacturing standardized worldwide bestsellers such as Fifty Shades of Grey (Illouz). In the era of globalization, the publishing industry has been increasingly dominated by large conglomerates that impose fierce criteria of commercial profitability and operation to the detriment of literary and intellectual criteria (Bourdieu "Conservative Revolution"; Schiffrin; Thompson). This concentration of production is reinforced by the concentration of distribution around chains such as Barnes \& Noble, which tend to focus on bestselling books. Consequently, many books are not even offered for sale by retailers. This is especially the case for books in translation in the United States, because of a collective belief in the weak commercial potential of translation.

Consequently, while the capitalist development of the book industry helped to free it from state control, the market can exert a commercial censorship that is only weakly counterbalanced by sales in independent bookstores and on the internet in the Us and the UK. Though the dynamics of globalization stimulated the local book industry in many countries and fostered cultural exchange through translation (the number of translations in the world increased by $50 \%$ between 1980 and 2000 according to the Index Translationum), the concentration process has had a negative impact on cultural diversity (Sapiro "Globalization"): the percentage of translations from English throughout the world rose from $45 \%$ in the 1980 s to $59 \%$ in the 1990 , according to the same source. At the same time, the share of translations in the Us and the UK was the lowest in the world: around $3 \%$.

To locate translations within the field of publishing, we need to understand its structure, which is polarized between large-scale and small-scale production (Bourdieu Field of Cultural Production; Bourdieu "Conservative Revolution"): the pole of large-scale production is ruled by the law of profitability in the short term (embodied by best-sellers), whereas at the pole of small-scale production, the specific logics and values of fields of cultural production, in our case the literary field, prevail over commercial considerations. This polarization also structures the world market of translations (Sapiro "Translation and the Field").

Translations from English are dominant in commercial genres (such as thrillers and romantic novels) and destined for the mass market, in which linguistic diversity is very low. Moreover, works translated from English often 
compete in this sector with book production in the original language, which developed later. The global circulation of these mass market products is fostered by transnational conglomerates on the one hand, and, on the other, by the propensity of publishers from different countries to imitate one another, that is to acquire the rights of books that were previously sold in another countryimitation being one of the processes explaining phenomena of isomorphism in markets (here the global book market; on isomorphism in publishing, see Franssen and Kuipers).

This observation also helps us explain why the share of translations is so weak in American and British book production: there are very few translations at the publishing field's pole of large-scale circulation, since they are considered unprofitable. By contrast, the pole of small-scale production is much more diversified with regards to the original languages from which books are translated, and this is all the more true in literature, which is the most diversified category of books: in France, for instance, translations account for more than one third of new literary titles, and originate from more than thirtysix languages and forty countries. However, commercial constraints also have more and more impact on the pole of small-scale production, especially in the Us and the UK, despite the active efforts of small independent publishers in the promotion of what they call "international literature" (Sapiro "Globalization").

\section{Cultural Factors}

The practice of translation preceded the emergence of the book market and contributed to its development. Historically speaking, the first bestseller in translation was the Bible, first printed in 1455 , and still the most translated text today (with around 400 full translations and 2300 partial ones). The wide diffusion of this sacred text in different languages was determined by religious factors as well as by the logics of the emerging market. Translations of the Bible existed, however, before it was circulated in printed form, and were a major issue at stake in the struggles that constituted the religious field.

Translation also played a crucial role in the formation of literary and publishing fields. By constituting a corpus of texts, it helped to standardize national languages, in some cases well before an indigenous production of texts in these languages developed. Translation also provided literary devices and models for writing modern fiction (Even-Zohar $45^{-52}$ ). This process underlies what Franco Moretti has called the "Jameson law," after Fredric Jameson's analysis of Japanese and Indian novels as hybrids of Western forms and local realities: 
"in cultures that belong to the periphery of the literary system (which means: almost all cultures, inside and outside Europe), the modern novel first arises not as an autonomous development but as a compromise between a western formal influence (usually French or English) and local materials" (Moretti 163). The most translated works formed the new canon of world literature (Casanova). This canon of modern literature in vernacular languages progressively replaced the classical Greco-Latin canon, which continued to be dominant on the world market of translation until the Second World War (Milo). Authors like Aeschylus, Sophocles, Euripides, Horace, Plutarch, Seneca, Plautus and Tacitus, who were among the sixty most translated authors at the beginning of the 1930s, according to the Index Translationum, disappeared from this list after the Second World War; Plato was the only one who survived. They were replaced by Tolstoy, Dickens, Dostoyevsky, and Balzac, to quote only the steadiest on the list of the thirty most translated writers.

The new canon was limited to European literature, apart from a few exceptions such as the Indian Nobel Prize winner Rabindranath Tagore. In the 1950s, UNESCO launched a program supporting translations from non-Western cultures in order to catalyze "literary interpenetration." This program encouraged editors and publishers to start translating classical and modern works from Asia and Latin America, expanding the borders of the international market of translations from Europe to the world (although whole areas like Sub-Saharan Africa were and are still excluded from this market). For instance, in France, the Sinologue René Étiemble created in 1953 a series titled "Connaissance de l'Orient." Though Communist China was not included in the Unesco projects, Étiemble persuaded the head of Gallimard that it was necessary to translate modern Chinese authors such as Lu Xun in order to attest to the "literary revolution" which had been taking place in the country since forty years earlier. As he explained to Roger Caillois, who was in charge of the UNESCO program, in a letter dated July 5, 1953, Étiemble's purpose was to render

accessible to the French educated public works of high literary quality that were never published in our language (or so badly translated that it is better not to talk about them), and chosen in order to illustrate the mores and cultural values in all the countries in question: India, China and Japan to begin with (but I would like to include Persia and the Arab world).

Neither the publisher nor myself are looking for immediate commercial success; we want to educate the public, to enlighten the Orient for them. But it goes without saying that we will have to, at the beginning especially, offer them titles that encourage them to educate themselves: 
novels that, while possibly entertaining them, inform them on people they are not familiar with. Most of the great novels from Asia are unknown in France.

GALLIMARD ARCHIVES; my translation

This letter emphasizes the pedagogic function ascribed to translations of upmarket foreign literatures, especially those issued from peripheral regions. The belief that literature can inform us about the culture and mores of a country, which also underlies the teaching of foreign languages and civilization in France as in other places, helps explain the rise of translations from certain peripheral languages. Despite the length and scope of the endeavor - the great Chinese novel Hong Leou Meng was 2500 pages long - ten titles had been published in this series by 1960. If, as expected, the sales were modest (1189 copies, on average), the series nevertheless filled a gap in French culture and publishing, and was thus highly praised by critics.

This series illustrates the specific logic of cultural fields, which gain autonomy from political and economic constraints (Bourdieu Rules of Art). This logic is irreducible to ideological or financial motivation. Many authors, translators, editors and even publishers undertake projects which they know will not bring them any commercial benefit, as Étiemble's quote exemplifies. Instead, they can expect symbolic profits such as recognition in the field.

Importing a literary work from one national field to another means that the work will be received out of the context of its creation, opening up a large space for interpretation and strategies of appropriation through labeling, prefaces, critics, etc., which can be understood only in light of the specific issues at stake in the reception field (Bourdieu "Social Conditions"; Damrosch). But the most important aspect of the reception process for literary history is probably the appropriation of foreign works as models for developing new narrative techniques and for subverting dominant literary norms: Faulkner and John Dos Passos were such sources for Jean-Paul Sartre, for instance (for more detailed examples of this type of appropriation, see Casanova).

\section{Social Factors}

The cultural factors at play in the circulation of literary works are embedded in power relations between social groups. For a long time, the canon of world literature was mainly composed of white, male, Western authors. As we have seen, it started to extend to non-Western cultures in the 1950s, thanks to a voluntary policy set up by UNESCO. Asian and Latin American authors began to 
achieve international recognition in the 1960 s and 7os. Literary prizes are a good indicator of this recognition. If we consider the most prestigious international prize, the Nobel, it was awarded to Miguel Ángel Asturias in 1967, Yasunari Kawabata in 1968, Pablo Neruda in 1971, and Gabriel García Márquez in 1982. The only Arab writer who has won it to date was Naguib Mahfouz in 1988. The recognition process took even more time for postcolonial authors, who had to develop specific strategies for drawing attention (Huggan; Brouillette; Moudileno). It was not until the 1980 s that African authors became visible on the international literary scene; Wole Soyinka, for example, was awarded the Nobel Prize in 1986. In 1987, for the first time, a Francophone Arab author, Tahar Ben Jelloun, won the French Goncourt Prize and became one of the most translated writers from French in the Us between 1990 and 2003, with six titles (on postcolonial Maghreb writers' access to the global market, see Lewis).

The consecration of postcolonial writers contributed to relativize national categories in the perception of literary works: whereas national, and consequently international literary authorities tended to promote "national" authors - those who had been rooted for more than two generations in the country, resided in the cultural centers, and were from the middle or upper classesa growing interest in writers formerly relegated to the margins because of their geographic or ethnic origins came to the fore around 1992. That year, the Saint-Lucian poet Derek Walcott was awarded the Nobel Prize, Sri-Lankan born Canadian novelist Michael Ondaatije the Booker, and Martinique-based Frenchman Patrick Chamoiseau the Goncourt. In France, the very notion of "world literature" was given a specific meaning in a manifesto titled "Pour une littérature-monde en français." Signed by 44 authors and published in Le Monde on March 15, 2007, by Jean Rouaud and Michel Le Bris, it contrasted peripheral, postcolonial and outward-looking émigré writers with well-established Parisian writers, accusing the latter of being cut off from the world and of narcissistic posturing. A collection of essays followed, published by Gallimard, while the manifesto aroused an international debate among specialists of French and Francophone Studies (see e.g. Miller). However, as pointed out by Ducournau, most of the manifesto signatories were themselves being published in Paris, in most cases with the prestigious publisher Gallimard, which ensured their visibility on the French and international literary markets. Indeed, as already seen, centrality and peripherality are mediated by the means of production.

Women were also marginalized by the literary authorities, although many of them had been active in the literary field and market since the nineteenth century. In France, the Goncourt literary prize, founded in 1902, was awarded for 
the first time to a woman, Elsa Triolet, in 1945. To protest against the Goncourt's misogyny, a group of 22 female writers launched in 1904 the Femina Prize, to be awarded to either female or male authors. As for the Académie française, Marguerite Yourcenar was the first woman to join its ranks in 1982, one year before the election of Senegal's Léopold Sédar Senghor. In the world market of translations, female authors are still underrepresented: only one quarter of the literary works translated from French in the us between 1990 and 2003 were authored by a woman, and one third of contemporary literature titles (Sapiro "Symbolic Capital"). Not to speak of the consecration of women by the Nobel Prize: female authors account for 12 out of 114 Nobel Prize Winners, i.e. less than $10 \%$. The pace picked up significantly starting in the 1990s, with seven female authors having won it since then-Nadine Gordimer, Toni Morrison, Elfriede Jelinek, Doris Lessing, Herta Müller, Alice Munro and Svetlana Alexievich-, versus only five women during the first ninety years of the twentieth century: Selma Lagerlöf, Grazia Deledda, Sigrid Undset, Gabriela Mistral, Nelly Sachs (with Shaï Agnon).

Following its globalization from the 196os onward, we thus observe a feminization of the world literary canon, parallel to the inclusion of postcolonial authors. Nevertheless, all these authors are published in the centers of the global literary market, and those writing in central languages are still more likely to get international recognition than those writing in peripheral languages.

\section{Conclusion}

Shortly after the replacement of the Classical canon by the Modern one, by the end of the 1950s, the number of uncanonized authors among the most translated writers increased significantly, due to the popularity of thrillers (such as those by Agatha Christie and Peter Cheney), and around 1970, such authors began to exceed the declining number of recognized authors (Milo). This evolution indicates that market demand has overtaken educational and cultural hierarchies. However, while the percentage of internationally consecrated authors (i.e. literary prize-winners) on the lists of bestsellers in the United States fell from $5 \%$ in the 1970 os to around $1 \%$ in the 1990 s, their presence grew in France and in Germany during the same period (Verboord). Thus the logic of the market does not spread in a homogenous way.

Moretti distinguishes two evolutionary models, waves and trees. These two models apply to the history of literature and they can be explained by two contrasting processes: isomorphism and differentiation. As analyzed by neo- 
institutional sociological theory, isomorphism results from three types of mechanism: constraint, imitation and professional norms (DiMaggio and Powell). These mechanisms apply to the conditions of the production of cultural goods. Constraint acts as the main homogenizing instrument in authoritarian regimes: the canon of socialist realism was in large part imposed by the USSR on the other Communist regimes. Imitation is typical of competitive free markets. Publishers will give preference to works already selected by their peers in other countries in order to reduce uncertainty (Franssen and Kuipers). Professional norms spread around the world through professional organizations, such as the publishers' international union, which is tied to national publishers' unions, or the PEN Club, which has local sections in each country. Literary agents also contribute to harmonizing the professional norms of national publishing fields. These norms may vary within the field of publishing, between the poles of large-scale and small-scale production; for instance, faithfulness to the original work and direct translation, two norms that have become widespread in upmarket publishing, do not apply in more commercial genres.

The norms of upmarket publishing clearly stem from the literary and academic fields, where originality has been a central value since the Romantic period. Originality is a principle of differentiation that counterbalances the tendency to isomorphism in creative industries. The principle of originality applies not only to the work of the cultural producer, recognized as a creator, but also to publishing: a literary publisher has an "identity," and functions as a "brand-name" which labels certain kinds of products; for example, some publishers played a role in gathering literary groups such as the nouveau roman around Éditions de Minuit. The significance of publishing brand-names in the world market is related to their symbolic capital, i.e. their renowned authors, their Nobel Prize winners and so on. Imitation occurs neither mechanically nor randomly. Publishers tend to follow the choices of some of their foreign peers rather than others. Elective affinities express identities, and thus distinction (Bourdieu Distinction). The principle of distinction also applies to nationstates, which all claim to have a national literature. The long-lasting prominence of the national as a category of literary classification, despite the globalization process, the emergence of multinational corporations and the growing isomorphism at the pole of large-scale production of the transnational field of publishing, is revelatory of this differentiation logic. Differentiation also applies to the "postcolonial exotic," defined by Graham Huggan as the "global 'spectacularization' of cultural differences" (Huggan 15). Finally, appropriation, which is never mechanical and cannot be reduced to mimicry, also introduces differentiation through the hybridization of genres and cultural traditions (Appadu- 
rai; Venuti 159). While the mechanisms favoring isomorphism translate into homogenizing waves, the differentiation process induces offshoots that shape trees. Swamped by the mass market, the pole of small-scale production constantly resurfaces and extends its ramifications.

\section{Works Cited}

Appadurai, Arjun. Modernity At Large: CulturalDimensions of Globalization. Minneapolis, MN: University of Minnesota Press, 1996.

Emily Apter, Against World Literature: On the Politics of Untranslatability. London: Verso. 2013.

Bourdieu, Pierre. Distinction: A Social Critique of the Judgement of Taste, tr. R. Nice, Cambridge, MA: Harvard University Press, 1984 [1979].

Bourdieu, Pierre. The Field of Cultural Production: Essays on Art and Literature, ed. R. Johnson, Cambridge: Polity Press, 1993.

Bourdieu, Pierre. The Rules of Art: Genesis and Structure of the Literary Field, tr. Susan Emanuel. Cambridge-Stanford: Polity Press-Stanford University Press, 1996 [1992].

Bourdieu, Pierre. "The Social Conditions of the International Circulation of Ideas." In Bourdieu: A Critical Reader, ed. Richard Shusterman. Oxford and Malden: WileyBlackwell, 1999 [1989], 220-228.

Bourdieu, Pierre. "A Conservative Revolution in Publishing," tr. Ryan Fraser, Translation Studies 1:2 (2008 [1999]), 123-153.

Brouillette, Sarah. Postcolonial Writers and the Global Literary Marketplace. New York: Palgrave Macmillan, 2007.

Casanova, Pascale. The World Republic of Letters, tr. M.B. DeBevoise. Cambridge, MA: Harvard University Press, 2004 [1999].

Damrosch, David. What is World Literature? Princeton, NJ: Princeton University Press, 2003.

DiMaggio, Paul J. and Powell, Walter W. "The Iron Cage Revisited: Institutional Isomorphism and Collective Rationality in Organizational Fields." American Sociological Review 48 (1983), 147-60.

Ducournau, Claire. Écrire, lire, élire l'Afrique. Les mécanismes de réception et de consécration d'écrivains contemporains originaires de pays francophones d'Afrique subsaharienne. PhD dissertation, Paris: École des hautes études en sciences sociales, 2012, forthcoming with CNRS Éditions.

Even-Zohar, Itamar. “Polysystem Studies." Poetics Today 11:1 (1990).

Franssen, Thomas, and Giselinde Kuipers. "Coping with Uncertainty, Abundance and Strife: Decision-Making Processes of Dutch Acquisition Editors in the Global Market for Translations." Poetics 41:1 (2013), 48-74. 
Heilbron, Johan. "Towards a Sociology of Translation: Book Translations as a Cultural World System." European Journal of Social Theory 2:4 (1999), 429-444.

Heilbron, Johan and Gisèle Sapiro. "Outline for a Sociology of Translation: Current Issues and Future Prospects.” In Constructing a Sociology of Translation, eds. Michaela Wolf and Alexandra Fukari, Amsterdam: John Benjamins, 2007, 93108.

Huggan, Graham. The Postcolonial Exotic: Marketing the Margins. London: Routledge, 2001.

Illouz, Eva. Hard-Core Romance: “Fifty Shades of Grey," Best-Sellers, and Society. Chicago, IL: University of Chicago Press, 2014.

Jacquemond, Richard "Translation Policies in the Arab World. Representations, Discourses, Realities." The Translator 15:1 (2009), 1-21.

Lewis, Mary Anne. The Maghreb Goes Abroad: The "Worlding" of Postcolonial North African Francophone Literature and Film in a Global Market. PhD dissertation, Yale University, 2013.

Loiseaux, Gérard. La Littérature de la défaite et de la collaboration, d'après "Phonix oder Asche?" de Bernhard Payr. Paris: Fayard, 1995.

Miller, Christopher. "The Theory and Pedagogy of a World Literature in French." Yale French Studies 120 (2011), 33-48.

Milo, Daniel. "La bourse mondiale de la traduction: un baromètre culturel." Annales 1 (1984), 92-115.

Moretti, Franco. "Conjectures on World Literature," New Left Review 1 (January-February 2000), 1-12; reprinted in David Damrosch, ed., World Literature in Theory. Oxford: Wiley-Blackwell, 2014.

Moudileno, Lydie. "Fame, Celebrity, and the Conditions of Visibility of the Postcolonial Writer." Yale French Studies 120 (2011), 62-74.

Pinhas, Luc. Éditer dans l'espace francophone: législation, diffusion, distribution et commercialisation du livre. Paris: Alliance des éditeurs indépendants, 2005.

Perucca, Brigitte. "La France règne en maître sur le marché des manuels scolaires en Afrique francophone". Le Monde, June 10, 2010.

Popa, Ioana. Traduire sous contraintes. Littérature et communisme. Paris: CNRs Éditions, 2010.

Rundle, Christopher. Publishing Translations in Fascist Italy. Oxford: Peter Lang, 2010.

Sapiro, Gisèle. "The Literary Field between the State and the Market." Poetics 31:5-6 (2003), 441-461.

Sapiro, Gisèle. "Translation and the Field of Publishing. A Commentary on Pierre Bourdieu's 'A Conservative Revolution in Publishing' from a Translation Perspective." Translation Studies 1:2 (2008), 154-167.

Sapiro, Gisèle. "Globalization and Cultural Diversity in the Book Market: The Case of Translations in the us and in France." Poetics 38:4 (2010), 419-39. 
Sapiro, Gisèle. "Strategies of Importation of Foreign Literature in France in the Twentieth Century: The Case of Gallimard, or the Making of an International Publisher." In Institutions of World Literature: Writing, Translation, Markets, eds. Stefan Helgesson and Pieter Vermeulen. London: Routledge, 2015, 143-159.

Sapiro, Gisèle. "Translation and Symbolic Capital in the Era of Globalization: French Literature in the United States." Cultural Sociology 9:3 (2015), 320-346.

Sapiro, Gisèle, ed. Translatio. Le marché de la traduction en France à l'heure de la mondialisation. Paris: CNRs Éditions, 2008.

Schiffrin, André. The Business of Books. Verso, New York, 2000.

Tarde, Gabriel. The Laws of Imitation. New York, NY: Henry Holt, 1903 [189o].

Thompson John B. Merchants of Culture: The Publishing Business in the Twenty-First Century. Cambridge: Polity Press, 2010.

Thomson-Wohlgemuth, Gaby. Translation under State Control: Books for Young People in the German Democratic Republic. New York and London: Routledge, 2009.

Venuti, Lawrence. The Scandals of Translation. Towards an Ethics of Difference. New York London: Routledge, 1998.

Verboord, Marc, "Market Logic and Cultural Consecration in French, German and American Bestseller lists, 1970-2007." Poetics 39:4 (2011), 290-315. 